\title{
ISSN: $1679-3013$ \\ D.O.I.: 10.5914/1679_3013.2014.0099 \\ POPULATION DYNAMICS OF Calanopia americana DAHL F., 1894 (COPEPODA, CALANOIDA) IN A REEF ENVIRONMENT IN TROPICAL BRAZIL
}

\author{
Valdylente T. PESSOA ${ }^{1}$ \\ Pedro A. M. C. MELO ${ }^{1}$ \\ Mauro MELO JÚNIOR ${ }^{2}$ \\ Sigrid NEUMANN-LEITÃO ${ }^{1}$
}

Recebido em: 06/02/2012

Aceito em: 10/02/2014

The present study aimed to analyze variations in population dynamics of the Copepoda Calanopia americana (C. americana) in a reef area in tropical Brazil. Diurnal and nocturnal samples were collected at a fixed station during ebb tide, over four lunar cycles, and in the dry and rainy seasons. C. americana presence was very frequent $(94 \%)$ and occurred in nearly all samples. Overall, juveniles presented higher densities than adults, and females were more abundant than males. There was a significant difference $(p<0.001)$ between the dry and rainy period for density, biomass and production, with the largest average values observed during the dry season ( 97.2 \pm 91.0 ind. $\mathrm{m}^{-3}, 157.64 \pm 131.80 \mu \mathrm{g} \mathrm{C} \mathrm{m}^{-3}$

\section{ABSTRACT}

and $34.20 \pm 30.36 \mu \mathrm{g} \quad \mathrm{m}^{-3}$ day $^{-1}$, respectively). In relation to the variation between day and night, the population dynamics of $C$. americana followed a pattern noted in previous studies, showing density peaks at $\left(522,3 \pm 402,68\right.$ ind. $\left.\mathrm{m}^{-3}\right)$ and lower values during the day $(324,0 \pm 336,36$ ind. $\mathrm{m}^{-3}$ ). During the dry season, the amount of available light coupled with a lower amount of suspended material interferes with the community by increasing the density and influencing the productivity of $C$. americana. Although some studies have shown the influence of the lunar cycle on the migration processes of $C$. americana, in this study these variation did not have significant influence on population dynamics.

Key-words: lunar cycle, plankton, production, biomass

\section{INTRODUCTION}

Copepods are crustaceans that play a key role in the marine ecosystem, and they feature a great diversity of species adapted to numerous (and variable) aquatic environments (BOULEY \& KIMMERER 2006). Among those occurring, in the tropical and subtropical Atlantic, one important species is Calanopia americana Dahl F., 1894 (Calanoida, Pontellidae). This species is smaller than most of the other members of its family and occurs mainly in coastal areas (BowMAN 1971). C. americana performs vertical migrations following a nocturnal or crepuscular pattern in both shallow coastal environments (areas less than 15 meters deep) and in deeper locations (oceanic waters greater than 700 meters deep) (BOWMAN 1971, CLARKE 1934, COHEN \& FORWARD 2002, TURNER et al. 1979). Individuals of this species, both males and females, are more frequently found in surface waters at night than during the day (CLARKE 1934).

Although not having very high density values Calanopia americana was a very frequent and dominant species throughout the study period. So the present study aimed to analyze variations in population dynamics of Calanopia americana in a reef area through a comparison of density, biomass and secondary production. Additionally, data were examined based on whether samples were collected in the dry or rainy seasons, during different phases of the moon and during the day and night.

\section{MATERIALS AND METHODS}

\section{Study area}

The municipality of Tamandaré is situated approximately $110 \mathrm{~km}$ south of the city of Recife, State of Pernambuco (Brazil). The climate is warm and humid and has a high annual rainfall (approximately 2,000 $\mathrm{mm}$ ), with the greatest concentration from May to September and 
PESSOA, V. T. et al. Population dynamics of Calanopia americana Dahl f., 1894 (Copepoda, Calanoida) in a reef environment in tropical Brazil.

in the remaining months of rainfall values are much smaller. The air temperature varies between 25 and $30{ }^{\circ} \mathrm{C}$ (MOURA \& PASSAVANTE 1994/95, NimER 1979). The transparency of the water fluctuates depending on the amount of rainfall and the terrestrial contribution, with a visibility ranging between 1 and 20 meters (MAIDA \& FERREIRA 1997).

Reef formations (sand stone) are present in the Bay of Tamandaré, which is part of an Environmental protection area (EPA) called "Costa dos Corais", covering an area of 34 by 135 $\mathrm{km}$ long (FERREIRA et al. 2001).

\section{Sample design}

Samples were collected at a fixed station inside of the Tamandaré Bay (The latitude $8^{\circ} 45^{\prime} \mathrm{S}$ and longitude $35^{\circ} 00^{\prime} \mathrm{W}$ ) during ebb tide, over four lunar cycles (neap tide - crescent and waning Moon; spring tide - full and new Moon), during the dry (november/december 2010) and rainy (july/august 2010) seasons and during the day and night time.

\section{Abiotic data}

Precipitation data were obtained from the National Institute of Meteorology (INMET). The surface water temperature was obtained by direct reading using a digital thermometer. The salinity values were determined by the method of Mohr-Knudsen as described by STRICKLAND \& PARSONS (1965). A membrane filter $(47 \mathrm{~mm}$ in diameter and $0.45 \mu \mathrm{m}$ porosity) was used to collect chlorophyll a samples, and the pigments were extracted using $90 \%$ acetone in the dark over $24 \mathrm{~h}$ at $-20{ }^{\circ} \mathrm{C}$. The readings chlorophyll $a$ were made in accordance with the Spectrophotometric method of UNESCO (1966), and calculations were performed using the equation of PARSONS \& STRICKLAND (1963), and the results expressed as $\mathrm{mg} \mathrm{m}^{-3}$. The amount of particulate material in suspension (PMS) was determined by the method of STRICKLAND \& PARSONS (1972).

\section{Biotics}

A total of fourty eight zooplankton samples were obtained through the use of horizontal subsurface tows using a plankton net ( $200 \mu \mathrm{m}$ mesh size). The collected material was fixed and stored according to the methodology described by SAMEOTO et al. (2000). The samples were analyzed by counting and measuring the first thirty copepods belonging to the species $C$. americana present in the subsamples (>300 individuals). Aliquots were obtained from each sample with a Motoda type fractionator (OMORI \& IKEDA 1984). The aliquots were examined in Bogorov plates under a stereoscopic microscope.

After calculation of the density (ind. $\mathrm{m}^{-3}$ ) and frequency of occurrence (\%) of C. americana, prosome measurements were taken for the first thirty organisms using a stereoscopic microscope. Then, the weight was estimated from the equation relating the weight to length of the prosome that is available in the literature. The morphometric equation used to calculate the carbon dry weight of $C$. americana was Ln W $=2.67$ Ln CP -15.47 according to CHISHOLM \& RoFF (1990). Organisms were classified by the stage of development (juveniles or adults) and gender (for adults only). Subsequently, for each sample, direct measurements were made of biomass (based on the average dry weight) and density. Growth rates were estimated based on the equation proposed by HIRST \& BUNKER (2003) to obtain secondary production data. For each sample, the production was obtained from the product between the growth rates and the biomass of the species.

\section{Statistics}

The density data were analyzed using a normality test (Kolmogorov-Smirnov). A Student t-test (when the distribution of the data was normal) and a Mann-Whitney test (for data with a non-normal distribution) were applied to verify significant differences between the dry and rainy seasons, between the phases of the moon and between daytime and nighttime periods. The statistical program SigmaPlot version 12 was used for all analyses, and a $p<0.05$ value was considered significant. 
PESSOA, V. T. et al. Population dynamics of Calanopia americana Dahl f., 1894 (Copepoda, Calanoida) in a reef environment in tropical Brazil.

\section{RESULTS}

\section{Abiotics}

The rainfall mean values ranged from 23.01 to $202.79 \mathrm{~mm}$ during the rainy season and between 0.50 and $21.62 \mathrm{~mm}$ in the dry season. The water surface temperature values ranged between $25.33 \pm 0.58$ and $27.50 \pm 0.50{ }^{\circ} \mathrm{C}$ during the rainy season and between $26.00 \pm 0.01$ and $28.0 \pm 0.01{ }^{\circ} \mathrm{C}$ during the dry period. Salinity ranged from $34.83 \pm 1.61$ to $37.16 \pm 0.76$ during the rainy season and between $36.66 \pm 0.58$ and $38.66 \pm 0.58$ during the dry period (Tables $1 \mathrm{a}$ and $1 \mathrm{~b}$ ).

Regarding the chlorophyll a data, the highest mean values were observed during the dry period $\left(1.49 \pm 0.23 \mathrm{mg} \mathrm{m}^{-3}\right)$, and the smallest mean values were found during the rainy season $\left(0.95 \pm 0.25 \mathrm{mg} \mathrm{m}^{-3}\right)$. The particulate material in suspension (PMS) data were highest during the rainy season $\left(23.76 \pm 2.70 \mathrm{mg} \mathrm{L}^{-1}\right)$ and lowest during the dry period $\left(8.65 \pm 3.12 \mathrm{mg} \mathrm{L}^{-1}\right)$ (Tables $1 a$ and $1 b$ ).

Table 1a - Abiotic data (mean values and standard deviation) collected during the rainy season dry (july/august 2010) in the reef area of Tamandaré, Pernambuco, Brazil.

\begin{tabular}{l|l|l|c|c|c|c}
\multicolumn{1}{c|}{ Turn } & Moon & Rain $(\mathbf{m m})$ & $\begin{array}{c}\text { Temp. } \\
\left({ }^{\circ} \mathbf{C}\right)\end{array}$ & Salinity & $\begin{array}{c}\text { Chl-a } \\
\left(\mathbf{m g . m}^{-3}\right)\end{array}$ & $\begin{array}{c}\text { PMS } \\
\left(\mathbf{m g} \cdot \mathbf{L}^{-\mathbf{1}}\right)\end{array}$ \\
\hline Diurnal & New & 118.68 & $27.50 \pm 0.50$ & $34.83 \pm 1.61$ & $1.26 \pm 0.53$ & $12.91 \pm 1.65$ \\
\hline Nocturnal & New & 118.68 & $27.50 \pm 0.50$ & $36.33 \pm 1.53$ & $1.28 \pm 0.26$ & $17.11 \pm 3.39$ \\
\hline Diurnal & Crescent & 168.79 & $27.50 \pm 0.50$ & $36.66 \pm 0.58$ & $0.956 \pm 0.25$ & $12.01 \pm 3.25$ \\
\hline Nocturnal & Crescent & 168.79 & $26.83 \pm 1.15$ & $36.33 \pm 0.58$ & $0.93 \pm 0.14$ & $12.01 \pm 2.17$ \\
\hline Diurnal & Full & 202.79 & $26.50 \pm 0.30$ & $37.16 \pm 0.76$ & $1.46 \pm 0.57$ & $23.76 \pm 2.70$ \\
\hline Nocturnal & Full & 202.79 & $26.50 \pm 0.40$ & $37.17 \pm 0.29$ & $1.52 \pm 0.23$ & $21.46 \pm 4.91$ \\
\hline Diurnal & Waning & 23.01 & $25.33 \pm 0.58$ & $36.66 \pm 0.58$ & $1.18 \pm 0.06$ & $18.70 \pm 3.14$ \\
\hline Nocturnal & Waning & 23.01 & $25.33 \pm 0.58$ & $36.67 \pm 0.58$ & $0.98 \pm 0.32$ & $18.73 \pm 3.31$ \\
\hline
\end{tabular}

Table 1b - Abiotic data (mean values and standard deviation) collected during the dry period (november/december 2010) in the reef area of Tamandaré Pernambuco-Brazil.

\begin{tabular}{l|l|l|l|l|l|l|}
\hline \multicolumn{1}{c|}{ Turn } & Moon & Rain $(\mathbf{m m})$ & $\begin{array}{c}\text { Temp. } \\
\left({ }^{\circ} \mathbf{C}\right)\end{array}$ & \multicolumn{1}{c|}{$\begin{array}{c}\text { Salinity } \\
\left(\mathbf{m g . m}^{-3}\right)\end{array}$} & $\begin{array}{c}\text { PMS } \\
\left(\mathbf{m g} \cdot \mathbf{L}^{-\mathbf{1}}\right)\end{array}$ \\
\hline Diurnal & New & 8.49 & $27.66 \pm 0.58$ & $36.66 \pm 0.58$ & $1.05 \pm 0.18$ & $9.09 \pm 0.54$ \\
Nocturnal & New & 8.49 & $26.33 \pm 1.15$ & $37.00 \pm 0.01$ & $1.24 \pm 0.30$ & $8.65 \pm 3.12$ \\
Diurnal & Crescent & 8.50 & $27.33 \pm 0.58$ & $38.00 \pm 0.01$ & $1.83 \pm 0.72$ & $11.79 \pm 0.74$ \\
Nocturnal & Crescent & 8.50 & $27.00 \pm 0.01$ & $38.00 \pm 0.01$ & $1.47 \pm 0.27$ & $10.45 \pm 0.93$ \\
Diurnal & Full & 21.62 & $26.00 \pm 0.01$ & $38.66 \pm 0.58$ & $1.4 \pm 0.53$ & $10.72 \pm 0.84$ \\
Nocturnal & Full & 21.62 & $27.33 \pm 0.58$ & $37.33 \pm 0.58$ & $1.49 \pm 0.23$ & $11.02 \pm 0.98$ \\
Diurnal & Waning & 0.50 & $28.00 \pm 0.01$ & $38.00 \pm 1.00$ & $1.38 \pm 0.57$ & $9.07 \pm 0.55$ \\
\hline Nocturnal & Waning & 0.50 & $27.66 \pm 0.58$ & $38.66 \pm 0.58$ & $1.47 \pm 0.35$ & $9.92 \pm 1.07$ \\
\hline
\end{tabular}

\section{Biotics}

C. americana was very frequent (94\%) during both the dry and the rainy seasons and was found in virtually all phases of the moon but also during the day and night time periods. When comparing the density values of $C$. americana with those of other species found in the study area, during the dry period, C. americana represented nearly $13.5 \%$ of the total density value during the day and $20 \%$ during the night (Figure 2 ). In the rainy season $C$. americana 
PESSOA, V. T. et al. Population dynamics of Calanopia americana Dahl f., 1894 (Copepoda, Calanoida) in a reef environment in tropical Brazil.

reached approximately $2.1 \%$ and $5.9 \%$ of the total density values for the day and night, respectively (Figure 2 ).

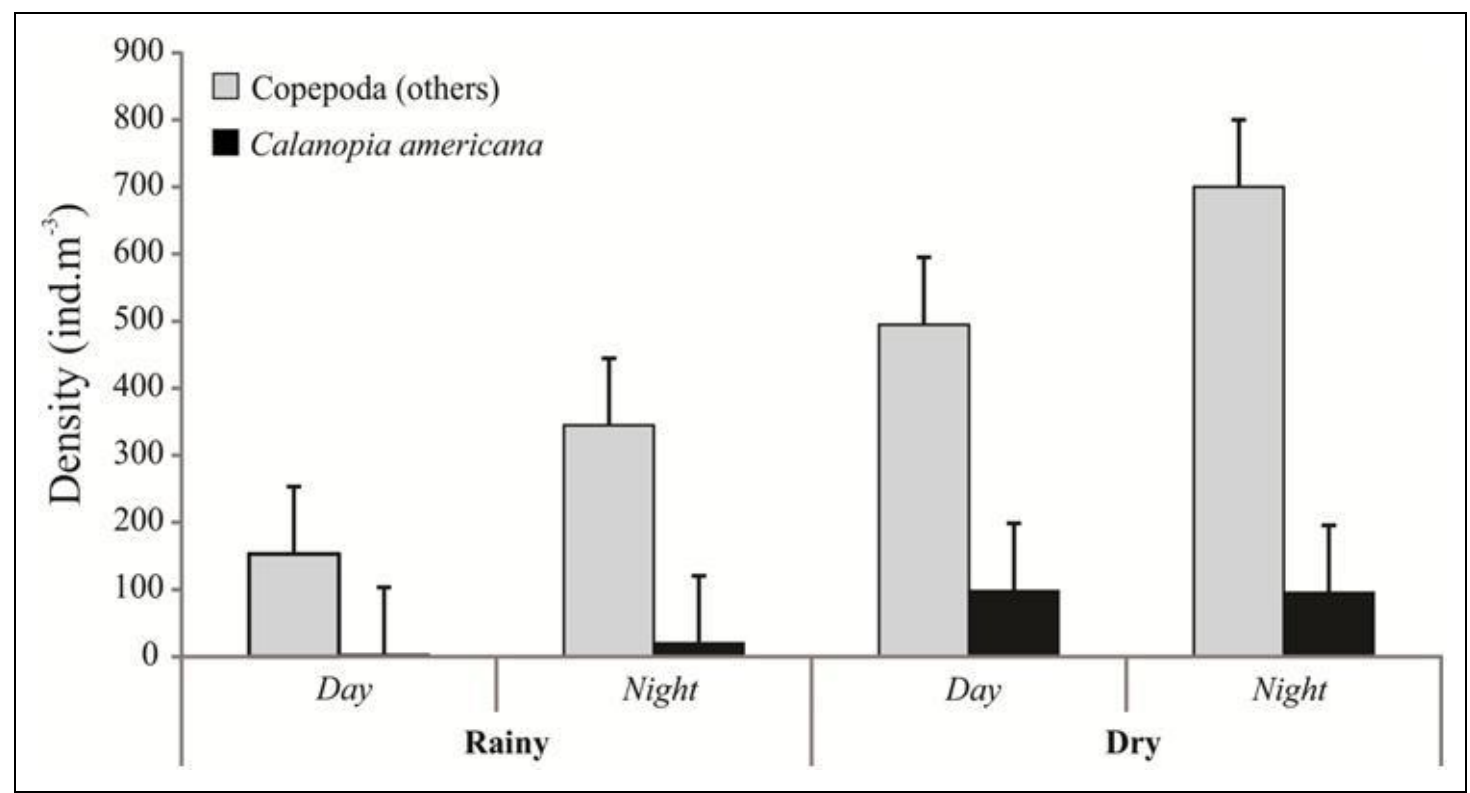

Figure 2 - Comparison of average density values (with standard deviation) between Calanopia americana and others Copepods found during the dry (november/december 2010) and rainy (july/august 2010) seasons in the reef area of Tamandaré, Pernambuco, Brazil.

Calanopia americana presented higher density mean values in the dry season $(97.2 \pm$ 91.0 ind. $\mathrm{m}^{-3}$ ) (Mann-Whitney, $\mathrm{p}<0.001$ ) and at night $\left(58.2 \pm 55.5\right.$ ind. $\mathrm{m}^{-3}$ ) (Mann-Whitney test; $p=0.020$ ) then in the rainy season and during the day, respectively (Figure 3 ). In relation to the influences of the lunar phases, the average values did not show significant differences (Kruskal-Wallis $\mathrm{p}=0.653$ ) (Figure 3 ). The average observed for the daytime period reflects the high density observed in a subset of samples that were associated mainly with the full moon phase.

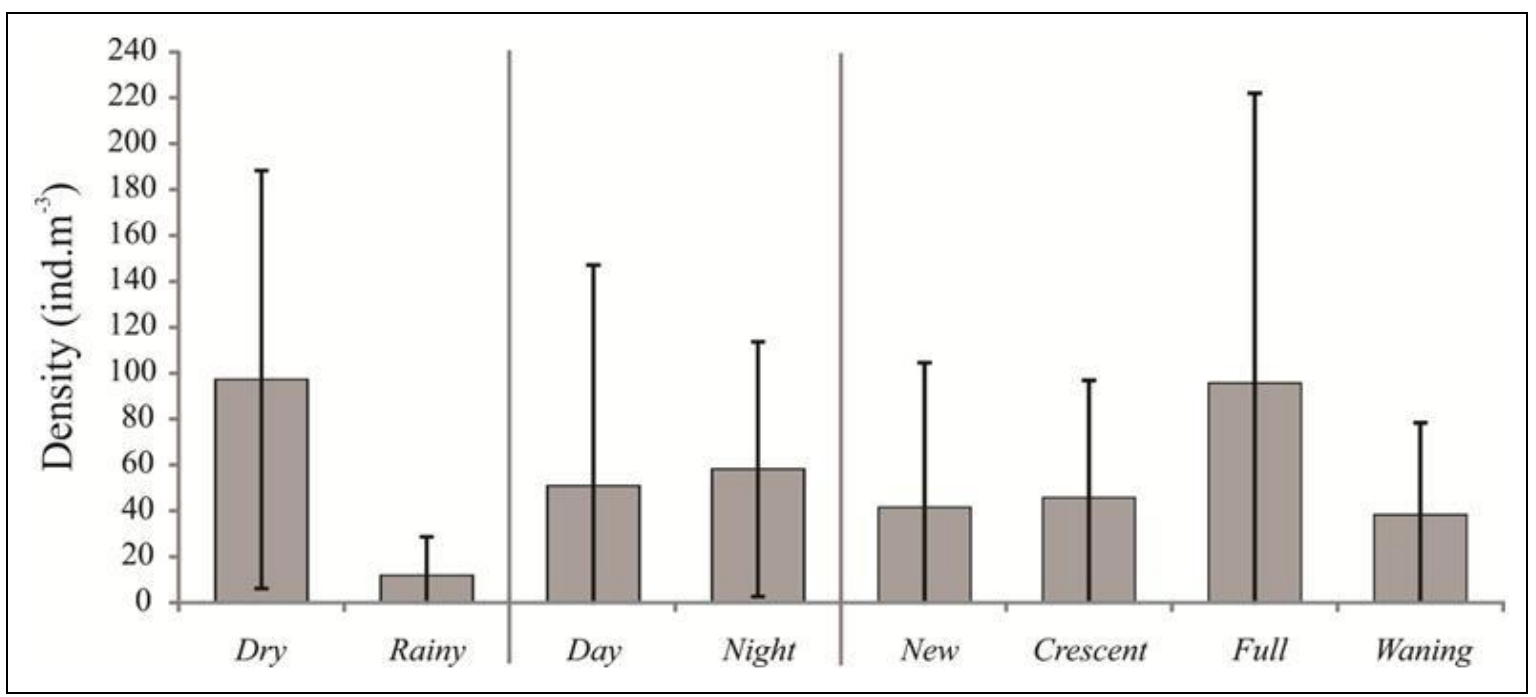

Figure 3 - Overall average with standard deviation of the density values of $C$. americana showing the differences observed between day and night, during the dry (november/december 2010) and rainy (july/august 2010) seasons and the lunar phases in the reef area of Tamandaré, Pernambuco, Brazil.

Considering the different development stages (juveniles and adults) and gender (males and females), the average density values showed that during all seasons, the juveniles 
PESSOA, V. T. et al. Population dynamics of Calanopia americana Dahl f., 1894 (Copepoda, Calanoida) in a reef environment in tropical Brazil.

presented higher densities, especially in the dry season, during a full moon and during both the day and night. The lowest density value was observed in the rainy season during the daytime period and the crescent moon phase. The number of adult females was always higher than the number of males when any factor analyzed was compared (Figure 4). Table 2 presents the values related to the calculation of the male/female ratio, where it can be observed that the highest proportions were associated with the dry period and daytime in the crescent moon phase and that the smallest proportions occurred during the rainy season.

There was a significant difference $(p<0.001)$ between the dry and rainy period for the biomass and production values of $C$. Americana, with the largest average values observed in the dry season (157.64 $\pm 131.80 \mu \mathrm{g} \mathrm{C} \mathrm{m}^{-3}$ and $34.20 \pm 30.36 \mathrm{\mu g} \mathrm{C} \mathrm{m}^{-3}$ day $^{-1}$ ) and the lowest in the rainy season $\left(0.30 \pm 0.27 \mu \mathrm{g} \mathrm{C} \mathrm{m}^{-3}\right.$ and $0.08 \pm 0.07 \mu \mathrm{g} \mathrm{C} \mathrm{m}^{-3}$ day $^{-1}$ ) (Table 3).

There was no significant difference in the production values of $C$. americana among the moon phases. A significant difference was observed for the production values between diurnal and nocturnal periods $(p=0.028)$. This indicates that the diurnal and nocturnal periods of the rainy season are different $(p<0.001)$, while this difference was not observed in the dry period.

The correlation between the biotic factors (density and biomass production) and abiotic factors (rainfall, temperature, salinity, chlorophyll $a$ and PMS) can be observed in Table 4. All of the biotic factors showed a negative correlation with rainfall and PMS. However, there was a positive correlation between salinity and chlorophyll $a$.

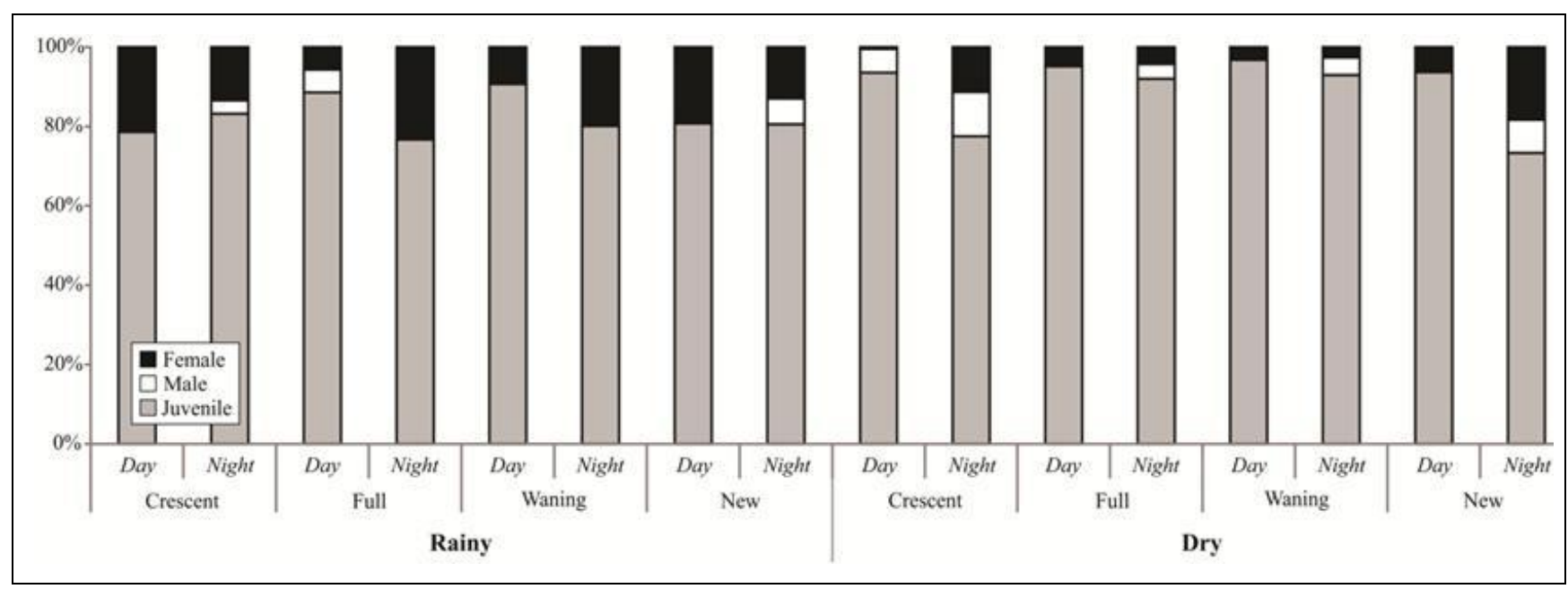

Figure 4 - The ratio of juvenile, male and female $C$. americana in the dry (november/december 2010) and rainy (july/august 2010) seasons, in different moon phases and during the day and the night at the reef area of Tamandaré, Pernambuco, Brazil.

Table 2 - Ratio of male and female of C. Americana in the the dry (november/december 2010) and rainy (july/august 2010) seasons, in different moon phases and during the day (D) and night ( $\mathrm{N})$ at the reef area of Tamandaré, Pernambuco, Brazil.

\begin{tabular}{|c|c|c|c|}
\hline Moon & Turn & Rainy & Dry \\
\hline \multirow{3}{*}{ New } & \multicolumn{3}{|c|}{ Male/Female } \\
\hline & $\mathrm{D}$ & 0.00 & 0.00 \\
\hline & $\mathrm{N}$ & 0.50 & 0.45 \\
\hline \multirow[t]{2}{*}{ Crescent } & $\mathrm{D}$ & 0.00 & 14.00 \\
\hline & $\mathrm{N}$ & 0.25 & 0.98 \\
\hline \multirow[t]{2}{*}{ Full } & $\mathrm{D}$ & 1.00 & 0.08 \\
\hline & $\mathrm{N}$ & 0.00 & 0.88 \\
\hline \multirow[t]{2}{*}{ Waning } & $\mathrm{D}$ & 0.00 & 0.00 \\
\hline & $\mathrm{N}$ & 0.00 & 1.67 \\
\hline
\end{tabular}


PESSOA, V. T. et al. Population dynamics of Calanopia americana Dahl f., 1894 (Copepoda, Calanoida) in a reef environment in tropical Brazil.

Table 3 - Variation in the biomass and production of $C$. americana (mean values and standard deviation) in the the dry (november/december 2010) and rainy (july/august 2010) seasons, in different moon phases and during the day and night at the reef area of Tamandaré, Pernambuco, Brazil.

\begin{tabular}{l|l|c|c|c|c}
\hline \multirow{2}{*}{} & \multicolumn{2}{|c|}{ Rainy } & \multicolumn{2}{c}{ Dry } \\
\cline { 2 - 6 } \multirow{2}{*}{ New } & Turn & $\begin{array}{c}\text { Biomass } \\
\left(\mu \mathrm{g} \mathrm{m}^{-3}\right)\end{array}$ & $\begin{array}{c}\text { Production } \\
\left(\mu \mathrm{g} \mathrm{C} \mathrm{m}^{-3} \text { day }^{-1}\right)\end{array}$ & $\begin{array}{c}\text { Biomass } \\
\left(\mu \mathrm{g} \mathrm{C} \mathrm{m}^{-3}\right)\end{array}$ & $\begin{array}{c}\text { Production } \\
\left(\mu \mathrm{g} \mathrm{m}^{-3} \text { day }^{-1}\right)\end{array}$ \\
\hline \multirow{2}{*}{ Crescent } & Diurnal & $0.30 \pm 0.27$ & $0.08 \pm 0.07$ & $43.23 \pm 58.72$ & $9.57 \pm 12.80$ \\
\cline { 2 - 6 } & Nocturnal & $9.91 \pm 3.18$ & $2.39 \pm 0.86$ & $83.98 \pm 79.32$ & $15.62 \pm 18.49$ \\
\hline \multirow{2}{*}{ Full } & Diurnal & $1.44 \pm 1.26$ & $0.36 \pm 0.32$ & $56.05 \pm 31.89$ & $13.87 \pm 7.33$ \\
\cline { 2 - 6 } & Nocturnal & $6.23 \pm 3.99$ & $1.63 \pm 1.04$ & $64.78 \pm 30.95$ & $15.28 \pm 7.50$ \\
\hline \multirow{2}{*}{ Waning } & Diurnal & $5.62 \pm 7.58$ & $1.34 \pm 1.79$ & $157.64 \pm 131.80$ & $34.20 \pm 30.36$ \\
\cline { 2 - 6 } & Nocturnal & $21.36 \pm 26.50$ & $4.92 \pm 6.25$ & $107.66 \pm 23.30$ & $24.35 \pm 4.88$ \\
\cline { 2 - 6 } & Diurnal & $11.49 \pm 10.10$ & $2.72 \pm 2.40$ & $11.11 \pm 7.62$ & $2.42 \pm 1.43$ \\
\cline { 2 - 6 } & Nocturnal & $19.17 \pm 9.31$ & $4.99 \pm 2.95$ & $57.95 \pm 25.59$ & $12.91 \pm 4.96$ \\
\hline
\end{tabular}

Table 4 - Correlation between the values of density, biomass, and production and the abiotic factors (rainfall, temperature, salinity, chlorophyll $a$ and particulate material in suspension) in the the dry (november/december 2010) and rainy (july/august 2010) seasons, in different moon phases and during the day and the night at the reef area of Tamandaré, Pernambuco, Brazil.

\begin{tabular}{llllll}
\hline & \multicolumn{1}{c}{ Rainfall } & Temperature & Salinity & $\begin{array}{c}\text { Chlorophyll } \\
\text { a }\end{array}$ & MPS \\
\hline Density & $\mathbf{- 0 . 6 7 5 * * *}$ & 0.0999 & $\mathbf{0 . 3 8 6 * *}$ & $\mathbf{0 . 3 4 8 *}$ & $\mathbf{- 0 . 3 9 9 * *}$ \\
Biomass & $\mathbf{- 0 . 5 6 6 * * *}$ & -0.0809 & $\mathbf{0 . 5 0 9 * * *}$ & $\mathbf{0 . 3 3 4 *}$ & $\mathbf{- 0 . 4 3 6 * *}$ \\
Production & $\mathbf{- 0 . 5 5 9 * * *}$ & -0.0844 & $\mathbf{0 . 4 9 3} * *$ & $\mathbf{0 . 3 3 4 *}$ & $\mathbf{- 0 . 4 2 5 * *}$ \\
\hline
\end{tabular}

$* \mathrm{p}<0.05 * * \mathrm{p}<0.01 * * * \mathrm{p}<0.001$

\section{DISCUSSION}

In northeastern Brazil, the water temperature variation between the rainy and dry periods rarely shows significant differences enough to directly influence the distribution of pelagic organisms. However, the difference in the intensity of rainfall between these two periods in many respects affects the aquatic environment, directly interfering with aquatic communities, especially in planktonic communities that are sensitive to changes in salinity, turbidity of the water and food availability. The patterns observed in this study were corroborated by previous studies (CAVALCANTI et al. 2008, MELO et al. 2012, NASCIMENTO-VIEIRA, et al. 2010, NEUMANN-LEITÃO et al. 2009).

Some studies suggest that the density of the zooplanktonic organisms may suffer due to light variation caused by the moon (HERNÁNDEZ-LEÓN 1998, HERNÁNDEZ-LEÓN et al. 2001) . There is a positive correlation between the abundance of some species of copepods and the cycles of the moon (HERNÁNDEZ-LEÓN 1998), and some species of copepods can accomplish vertical migrations exceeding $200 \mathrm{~m}$ influenced by moonlight (HERNÁNDEZ-LEÓN et al. 2001). Previous studies have shown obvious effects of the full moon on some communities of pelagic copepods; however, in this work, the different lunar cycles did not seem to significantly influence the distribution of $C$. americana. 
PESSOA, V. T. et al. Population dynamics of Calanopia americana Dahl f., 1894 (Copepoda, Calanoida) in a reef environment in tropical Brazil.

In this study, the density, biomass and productivity of $C$. americana were mainly higher during the night time. It is common for marine Copepods to exhibit vertical movements in the water column during the diurnal cycle. The most common pattern is a rise in the water column (to near the surface) at sunset and a descent to the maximum depth around sunrise (MELO et al. 2010). Studies conducted with C. americana show that this species is sensitive to light intensity variation throughout the day and it is found among plankton surface samples at night (COHEN ; FORWARD 2002). This diurnal vertical migration is hypothesized to decrease mortality risk by functioning as a refuge from visual predation in weak light areas at depth and provide nighttime access to food-rich surface waters (DE ROBERTIS et al. 2001, FORWARD 1988, FROST 1988). C. americana shows strong nocturnal vertical migration characteristics (CLARKE 1934) and has also shown a seasonal shift in distribution off the coast of North Carolina (USA). This species has previously shown high near shore numbers in the summer and fall months but is found largely offshore in the winter and spring months near Cape Hatteras and southern Florida (BOWMAN 1971).

Variations in the population dynamics of $C$. americana in tropical Brazil, mainly in a coastal reef region, appears to be directly related to the seasonal variation due to the regional interference effect of rainfall. The significant increase in suspended material caused by excessive rains reduced the availability of light and food. In addition, these rains interfered with the influence of light on vertical movement ability in the water column.

During the dry season, the amount of available light coupled with a lower amount of suspended material interferes with the community by increasing the density and influencing the productivity of $C$. americana. Although previous studies have shown the influence of the lunar cycle on the migration processes of $C$. americana, in this study, the lunar cycle variation did not cause a significant influence on population dynamics.

In relation to the variation between day and night, the population dynamics of $C$. americana in this study follow the pattern already noted in previous studies: density peaks were observed at night, and lower values were observed during the day. This fluctuation strategy is associated with reproduction, the search for food and protection against predation.

\section{ACKNOWLEDGEMENTS}

The authors thank the FACEPE and the CNPq (National Council of Scientific and Technological Development) for their financial support during the development of this research.

\section{REFERENCES}

BOULEY, P.; KIMMERER, W.J. Ecology of a highly abundant, introduced cyclopoid copepod in a temperate estuary. Marine Ecology Progress Series, v. 324, p. 219-228, 2006.

$10.3354 /$ meps324219.

BOWMAN, T.E. The Distribution of Calanoid Copepods Off the Southeastern United States between Cape Hatteras and Southern Florida. Smithsonian Contributions to Zoology, v. 96, p. 1-58, 1971.

CAVAlCANTI, E. A. H.; NEUMANN-LEITÃO, S.; VIEIRA, D. A. D. N. Mesozooplâncton do sistema estuarino de Barra das Jangadas, Pernambuco, Brasil. Revista Brasileira de Zoologia, v. 25, p. 436-444, 2008.

CHISHOLM, L. A.; ROFF,C. Size-weight relationships and biomass of tropical neritic copepods off Kingston, Jamaica. Marine Biology, v. 106, n. 1, p. 71-77, 1990.

CLARKE, G. L. The diurnal migration of copepods in St. Georges Harbor, Bermuda. Biological Bulletin, v. 67, n. 3, p. 456-460, 1934.

COHEN, J. H.; FORWARD, R. B. Spectral Sensitivity of Vertically Migrating Marine Copepods. The Biological Bulletin, v. 203, n. 3, p. 307-314, 2002.

DE ROBERTIS, A.; JAFFE, J. S.; OHMAN; M.D. Size-dependent visual predation risk and the timing of vertical migration in zooplankton. Limnology and Oceanography, v. 45, n.8, p. 1838-1844, 2001. 
PESSOA, V. T. et al. Population dynamics of Calanopia americana Dahl f., 1894 (Copepoda, Calanoida) in a reef environment in tropical Brazil.

FERREIRA, B. P.; CAVA, F.; MAIDA, M. Composição da pescaria recifal observada na Área de Proteção Ambiental Costa dos Corais, Tamandaré - PE-Brasil. In: Congresso Latino Americano de Ciências do Mar, San Andres, Colômbia, . p. 213-216. 2001.

FORWARD, R. B. Diel vertical migration: zooplankton photobiology and behaviour.

Oceanography and Marine Biology, An Annual Review, v. 26, 361-393, 1988.

FROST, B. W. Variability and possible adaptive significance of diel vertical migration in Calanus Pacificus, a planktonic marine copepod. Bulletin of Marine Science, v. 43, n.3, p. 675-694, 1988.

HERNÁNDEZ-LEÓN, S. Annual cycle of epiplanktonic copepods in Canary Island waters.

Fisheries Oceanography, v. 7, n. 3-4, p. 252-257, 1998. 10.1046/j.1365-

2419.1998.00071.x.

HERNÁNDEZ-LEÓN, S.; ALMEIDA, C.; YEBRA, L.; ARÍSTEGUI, J.; FERNÁNDEZ DE PUELLES, M.L.; GARCÍA-BRAUN, J. Zooplankton abundance in subtropical waters: is there a lunar cycle? Scientia Marina, v. 65, Suppl. 1, p. 59-64, 2001.

HIRST, A. G.; BUNKER, A. J.. Growth of marine planktonic copepods: Global rates and patterns in relation to chlorophyll a, temperature, and body weight. Limnology and Oceanography, $v$. 48, n. 5, p. 1988-2010, 2003.

MAIDA, M.; FERREIRA, B .P.. Coral reefs of Brazil: an overview. In: 8th International Coral Reefs Symposium, Panama City, p. 263-274, 1997.

MELO, P. A. M. C.; DIAZ, X. F. G.; MACEDO, S. J. D.; NEUMANN-LEITÃO, S. Diurnal and spatial variation of the mesozooplankton community in the Saint Peter and Saint Paul Archipelago, Equatorial Atlantic. Marine Biodiversity Records, v. 5, p. 1-14, 2012. doi:10.1017/S1755267212001054.

MELO, P. A. M. C.; SILVA, T.A.; NEUMANN-LEITÃO, S.; SCHWAMBORN, R.; GUSMÃO, L. M. O.; PORTO NETO, F.F. Demersal zooplankton communities from tropical habitats in the southwestern Atlantic. Marine Biology Research, v. 6, n. 6, p. 530-541, 2010. 10.1080/17451000903426557.

MOURA, R. T.; PASSAVANTE, J. Z. de O. Biomassa Fitoplanctônica da Baía de Tamandaré, Rio Formoso - Pernambuco, Brasil. Trabalhos Oceanográficos da Universidade Federal de Pernambuco, v. 23, p. 1-16, 1994/95.

NASCIMENTO-VIEIRA, D. A.; NEUMANN-LEITÃO, S.; PORTO NETO, F. F.; SILVA, T. A.; SILVA, A.P.. Mesozooplâncton de área recifal do Atlântico sudoeste Tropical. Tropical Oceanography, v. 38, n. 1, p. 45-59, 2010.

NEUMANN-LEITÃO, S.; FEITOSA, F. A. N.; MAYAL, E.; SCHWAMBORN, R.; SILVA-CUNHA, M. G. G.; SILVA, T. A.; PORTO NETO, F. F. The Plankton From Maracajaú Reef Ecosystem (Brazil) Offshore Coral Reefs Under Multiple Human Stressors. WIT Transactions on Ecology and the Environment, v. 122, p. 173-182, 2009.

NIMER, E. Climatologia do Brasil. IBGE, Rio de Janeiro, p. 421, 1979.

OMORI, M.; IKEDA, T. Methods in marine zooplankton ecology. Wiley-Interscience Publications, New York., p. 331, 1984.

PARSONS, T. R.; STRICKLAND, J. D. H. Discussion of spectrophotometric determination of marine-plant pigments, with revised equations for ascertaining chlorophylls and carotenoids.

Journal of Marine Research, v. 21, p. 155-163, 1963.

SAMEOTO, D.; WIEBE, P.; RUNGE, J.; POSTEL, L.; DUNN, J.; MILLER, C.; COOMBS, S.

Collecting zooplankton, p. 55-81. In: Roger, H., W. Peter, L. Jürgen, S. Hein Rune \& H. Mark (eds) ICES Zooplankton Methodology Manual. Academic Press, London, 2000.

STRICKLAND, J. D. H.; PARSONS, T.R. A manual of sea water analysis. V. 125, 2nd, p. 203. 1965. 
PESSOA, V. T. et al. Population dynamics of Calanopia americana Dahl f., 1894 (Copepoda, Calanoida) in a reef environment in tropical Brazil.

STRICKLAND, J. D. H.; PARSONS, T. R. A practical handbook of seawater analysis, 2nd. Fisheries Research Board of Canada, Ottawa, 1972.

TURNER, J. T.; COLLARD, S. B.; WRIGHT, J. C.; MITCHELL, D. V.; STEELE; P. Summer Distribution of Pontellid Copepods in the Neuston of the Eastern Gulf of Mexico Continental Shelf. Bulletin of Marine Science, v. 29, n.3, p. 287-297, 1979.

UNESCO. Determination of Photosynthetic Pigments in Sea-water. United Nations Educational, Scientific, and Cultural Organization, Paris, p. 337, 1966. 